UDC 661.847.92

\title{
SYNTHESIS, CHARACTERISTIC AND ACTIVITY OF NANOSIZED Cu-Me (Me-Co, Zn, Ni) OXIDE SYSTEMS IN CO OXIDATION IN THE PRESENCE OF $\mathrm{H}_{2}$
}

\author{
S.T.Jafarova \\ M.Nagiev Institute of Catalysis and Inorganic Chemistry, NAS of Azerbaijan \\ rsevil7@gmail.com
}

Received 12.10.2020

Accepted 14.12.2020

\begin{abstract}
Nanooxides of $\mathrm{Cu}-\mathrm{Me}$ composition ( $\mathrm{Me}-\mathrm{Co}, \mathrm{Zn}, \mathrm{Ni}$ ) were synthesized by hydrothermal reduction of metal salts with subsequent calcination and the influence of their properties (size, morphology, structure) on catalytic activity of deep $\mathrm{CO}$ oxidation reaction in the presence of $\mathrm{H}_{2}$ was considered. The nanooxides have been characterized by XRD and SEM methods. It was revealed that particles of $\mathrm{Cu}-\mathrm{Co}-\mathrm{O}$ are nanoplates $(30-35 \mathrm{~nm})$, and $\mathrm{Cu}-\mathrm{Zn}-\mathrm{O}(12.5-20 \mathrm{~nm})$ are nanorods. The SEM method revealed a higher structural organization of the $\mathrm{Cu}-\mathrm{Co}-\mathrm{O}$ particles than $\mathrm{Cu}-\mathrm{Zn}-\mathrm{O}$; the growth of nanocrystals is shown by varying the magnification of the scale grid of images. The highest activity of the $\mathrm{Cu}-\mathrm{Co}-\mathrm{O}$ system was found among the mentioned and corresponding individual oxides. The effect of metal $(\mathrm{Cu} / \mathrm{Co})$ ratio on the dispersibility and morphology of nanoparticles and their activity has been studied. The non-additive increase in activity is explained by the redox properties of cobalt oxides and the contribution of copper to electronic state of this element. The variation of composition, as well as high dispersibility $(30-35 \mathrm{~nm})$ make it possible to reduce the temperature of oxidation beginning $\left(\mathrm{T}_{50 \%}\right)$ of $\mathrm{CO}$ to less than $115^{\circ} \mathrm{C}$.
\end{abstract}

Keywords: nanooxides, nanoplates, nanorods, modification, morphology, structure, CO oxidation, electron microscopy.

doi:

The reaction of deep $\mathrm{CO}$ oxidation in the presence of $\mathrm{H}_{2}$ makes it possible to clean up hydrogen gases intended for fuel cells from the CO impurities [1]. A significant number of scientific publications have been devoted to the selective catalytic oxidation of $\mathrm{CO}$, but the vast majority of works are based on noble and rare earth metals [2-6], the cost and limited availability of which prevents their widespread use, and therefore these works remain at the level of academic research. Replacement of expensive materials with relatively cheap ones - transition metal oxides is the main line of research today [7-10].

The main problem in the development of deep CO oxidation catalysts is the reduction of their operating temperature, which can be achieved by reducing the dispersion of the catalysts used [11, 12]. Researchers using different methods of synthesis of nanoparticles of the same composition note differences in their structure, morphology and properties. The question of determining the relationship between material characteristics (size, structure, morphology) and activity remains open. In present work an attempt is made to determine the factors influencing the $\mathrm{CO}$

oxidation process on nanoscale structures obtained by hydrothermal reduction of metal salts. We have applied this approach to the oxidation of $\mathrm{CO}$ on copper-containing systems, which are most traditionally used in the process of deep $\mathrm{CO}$ oxidation, as well as because of the increased interest in recent years to its application in this reaction [13-15]. Earlier [16] we studied the mechanism of hydrothermal reduction of metal salts with the production of the $\mathrm{Cu}-\mathrm{Co}-\mathrm{Al}$ oxide system and showed the formation of hydroxyoxalates as intermediate synthesis products.

In the present work, the oxide systems of $\mathrm{Cu}-\mathrm{Me}(\mathrm{Me}-\mathrm{Co}, \mathrm{Zn}, \mathrm{Ni})$ have been synthesized and characterized. The resulting properties of nanomaterials (size, morphology, structure) and their influence on catalytic activity in the oxidation of $\mathrm{CO}$ in the presence of $\mathrm{H}_{2}$ have been considered.

\section{Experimental part}

Nanoparticles are synthesized in an autoclave by the hydrothermal method, which consists of the thermal decomposition of a mixture of metal nitrates in a glycerol medium. The method is described in detail in [16]. Before 
characterisation and catalytic testing, all samples are dried at $110^{\circ} \mathrm{C}$ and calcined at 500$550^{\circ} \mathrm{C}$ for 2 hours.

$\mathrm{X}$-ray phase analysis of samples was performed on a D2 Phaser diffractometer (Bruker) in monochromatic $\mathrm{Cu} K_{\alpha}$ radiation in the range of diffraction angles $2 \theta$ from 50 to $80^{\circ}$. The size of nanoparticles was determined by the Scherrer equation. Scanning electron microscopy was performed on the Sigma VP (Carl Zeiss) microscope to determine the morphology and size of the particles.

The catalytic activity of samples was studied in a quartz microreactor of flow type. The catalyst load was $0.1 \mathrm{~cm}^{3}$. The reaction temperature was determined in the middle of the catalyst layer by a chromel-alumel thermoscouple. The activity is calculated on $\mathrm{CO}$ conversion degree. The initial reaction mixture contained $1.6 \% \mathrm{CO}$ with a ratio of $\mathrm{CO} / \mathrm{O}_{2}=1.32$, the rest being hydrogen.

\section{Results and discussion}

Synthesis of the Cu-Me (Me-Co, Zn, Ni) system, structure and morphology control

Interpretation of diffractograms of $\mathrm{Cu}-$ Co synthesis products showed formation of cobalt and copper oxides. The influence of $\mathrm{Cu}-\mathrm{Co}$ metal ratio on structure and morphology was studied. It was found that regardless of the ratio of metals copper oxides (PDF 000050661) and cobalt oxides are formed, with only cobalt oxide structure difference.

At $\mathrm{Cu} / \mathrm{Co}$ ratio is equal to unity, $\mathrm{Co}_{2.83} \mathrm{O}_{4}$
(PDF 010785621) is formed, at $\mathrm{Cu} / \mathrm{Co}=1 / 2$ (Figure 1 a), $\mathrm{CoO}$ (PDF 030655474 (C)) with a tetragonal structure and $\mathrm{Co}_{3} \mathrm{O}_{4}(\mathrm{PDF} 010761802$ (A)) with a cubic structure $a=b=c=8.072$. In case ratio $\mathrm{Cu} / \mathrm{Co}=1 / 4$, the $\mathrm{XRD}$ reflections characteristic to copper oxide are not traced in the diffractogram (Figure $1 b$ ), but reflections characteristic of $\mathrm{Co}_{3} \mathrm{O}_{4}$ (PDF 000090418 (D)) with a cubic structure $a=b=c=8.084$ are observed. The absence of XRD reflections characteristic to copper oxides is apparently explained by its greater dispersion. Faceting degree of $\mathrm{Co}_{3} \mathrm{O}_{4}$, measured as the ratio of intensities (311)/(220) of X-rays [17], indicated an increase in the degree of faceting in favor of the product obtained at the ratio $\mathrm{Cu} / \mathrm{Co}=1 / 2$.

The effect of the $\mathrm{Cu} / \mathrm{Co}$ ratio on surface morphology and particle size was studied by SEM method. To study the issue of changes in surface morphology, the phases of formation of crystal nuclei were studied. Varying the magnification of the scale grid allows us to observe the growth picture as a whole (Figure 2).

Figure $2(a, c)$ shows the initial stage of crystal structure formation. Crystal colonies are then formed, which at $\mathrm{Cu} / \mathrm{Co}=1 / 4$ increase to $30-35 \mathrm{~nm}$, and at $\mathrm{Cu} / \mathrm{Co}=1 / 4$ to more than 140 $\mathrm{nm}$, i.e. the increase in cobalt among increases the size of nanocrystals.

Thus, it is visually confirmed that defects formed on the specimen surface in the form of long spike-like outgrowths are additional centers for crystal growth.

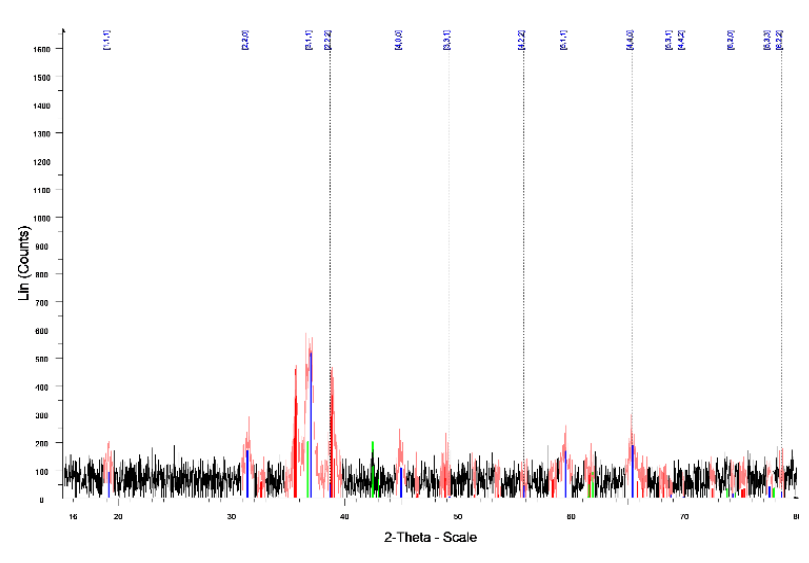

a) green - $\mathrm{CoO}$; blue $-\mathrm{Co}_{3} \mathrm{O}_{4}$; red - $\mathrm{CuO}$

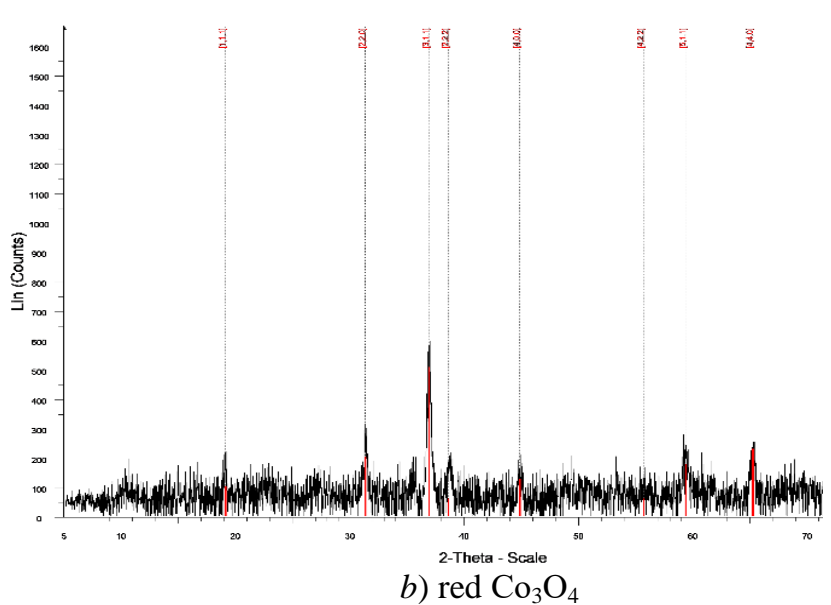

b) $\mathrm{red} \mathrm{Co}_{3} \mathrm{O}_{4}$

Fig. 1. Diffractograms of the $\mathrm{Cu}-\mathrm{Co}$ oxide system nanoparticles depending on the $\mathrm{Cu} / \mathrm{Co}$ ratio: $1 / 2(a)$ and $1 / 4(b)$. 


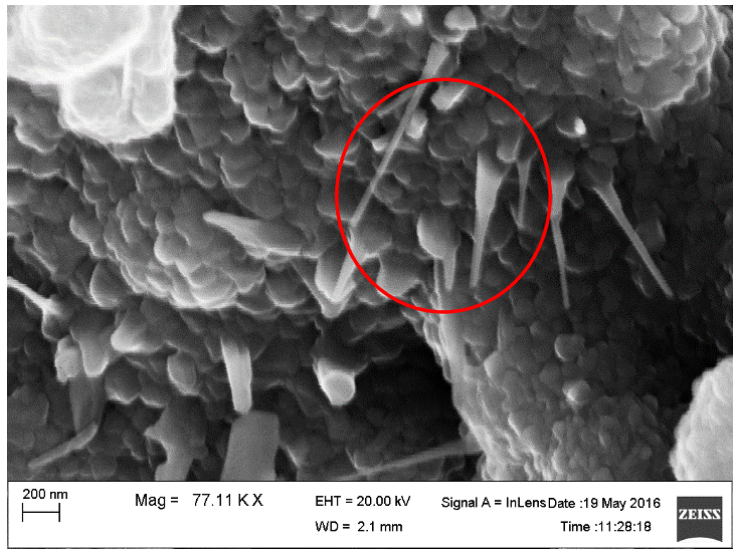

$a(200 \mathrm{~nm})$
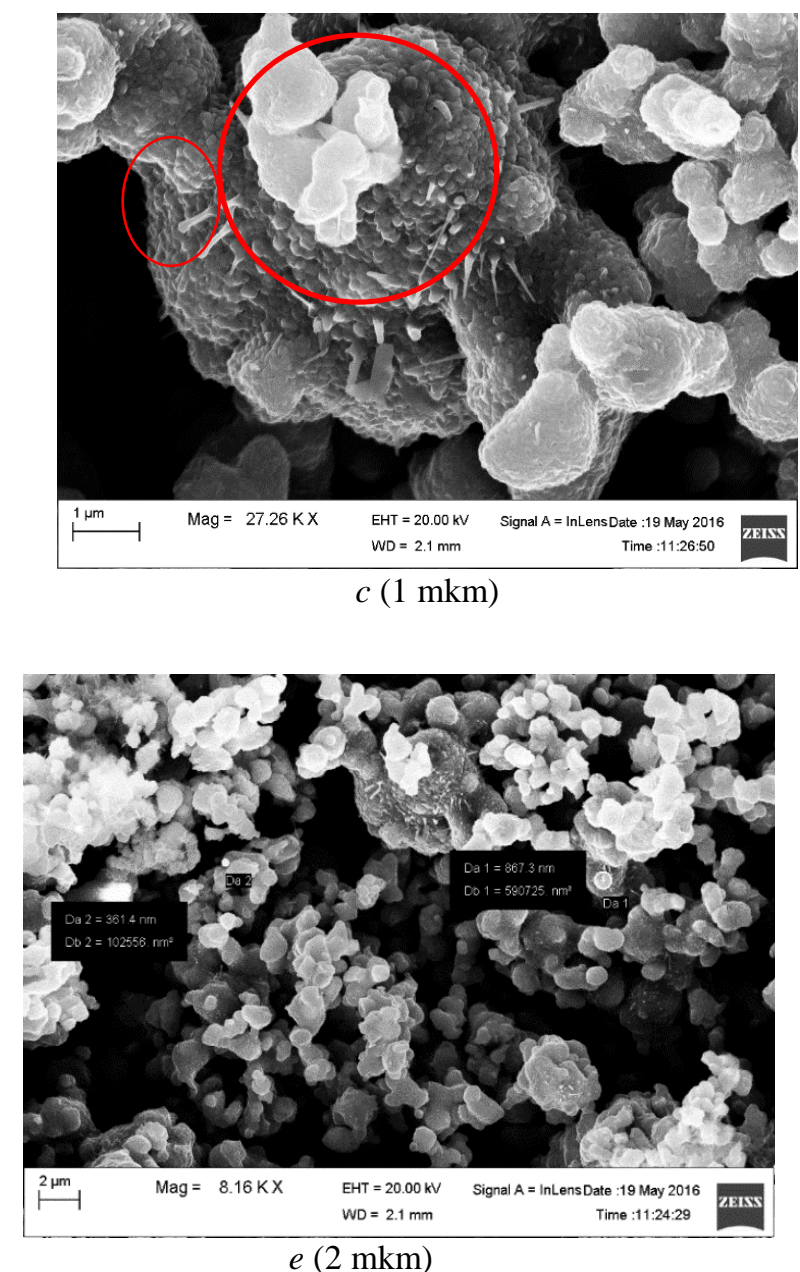

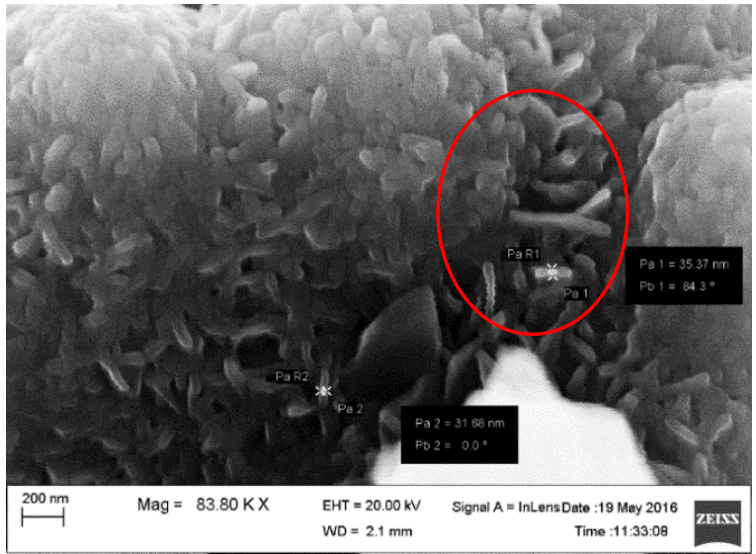

$b(200 \mathrm{~nm})$
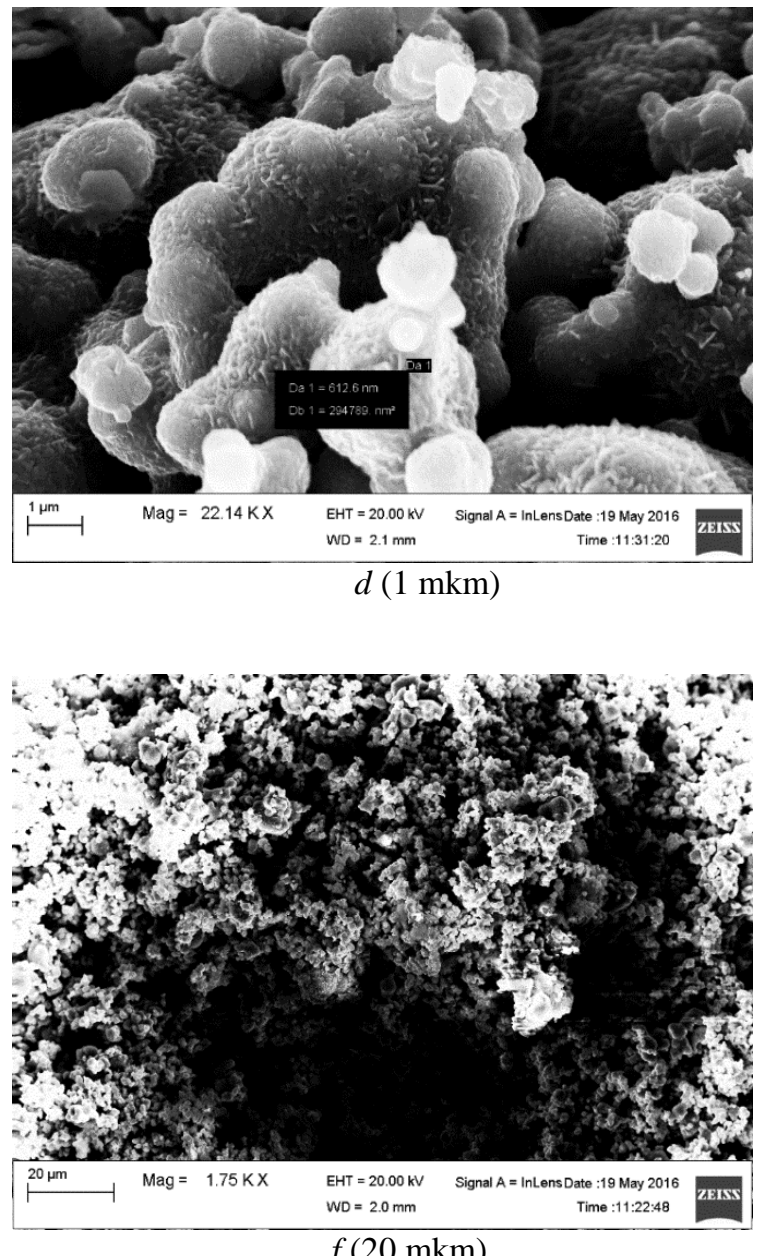

Fig. 2. SEM image of nanoparticles of the $\mathrm{Cu} / \mathrm{Co}$ oxide system in variation of scaling grid magnification.

Chemical analysis of sample surfaces (Figure 3) showed the simultaneous presence of both metals in the surface layer, although the XRD (Figure $1 b$ ) showed no reflections characteristic of copper oxides. An increased cobalt content is observed on the surface of both samples.

In the case of $\mathrm{Cu} / \mathrm{Co}$ in a $1 / 2$ ratio (Figure
3 a), 64.1 mass \% Co and 35.0 mass $\% \mathrm{Cu}$ are observed, with a $1 / 4$ ratio (Figure $3 b$ ) -79.3 mass \% $\mathrm{Co}$ and 16.3 mass $\% \mathrm{Cu}$, that is, the ratio of the components on the surface corresponds to 0.54 and 0.21 . Consequently, the ratio of elements on the surface corresponds to the ratio of elements in the initial solutions. 


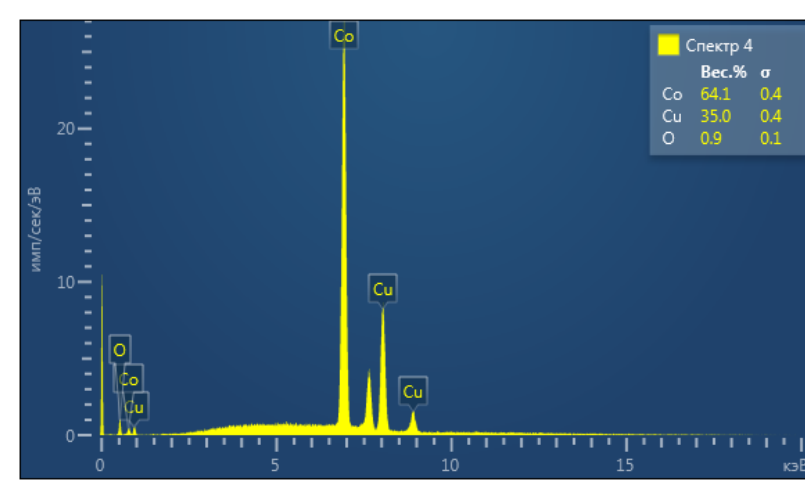

$a$

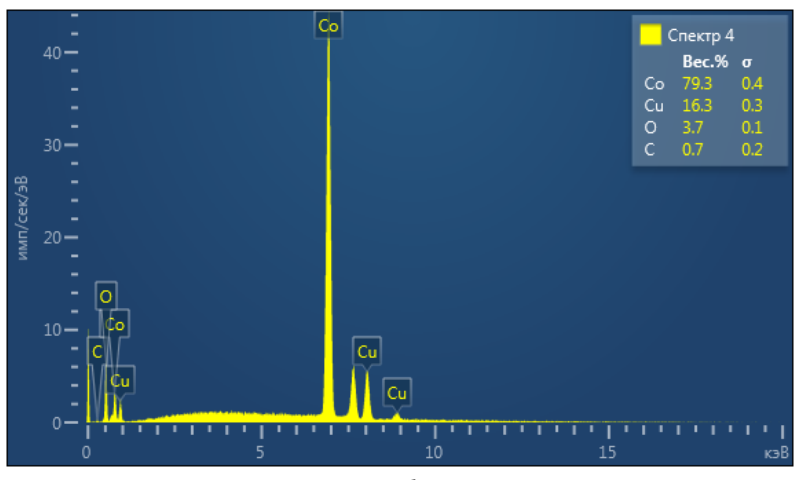

$b$

Fig. 3. Elemental analysis spectra of the surface of the $\mathrm{Cu}-\mathrm{Co}$ oxide system nanoparticles as a function of the $\mathrm{Cu} / \mathrm{Co}$ ratio: $1 / 2(a)$ and $1 / 4(b)$.

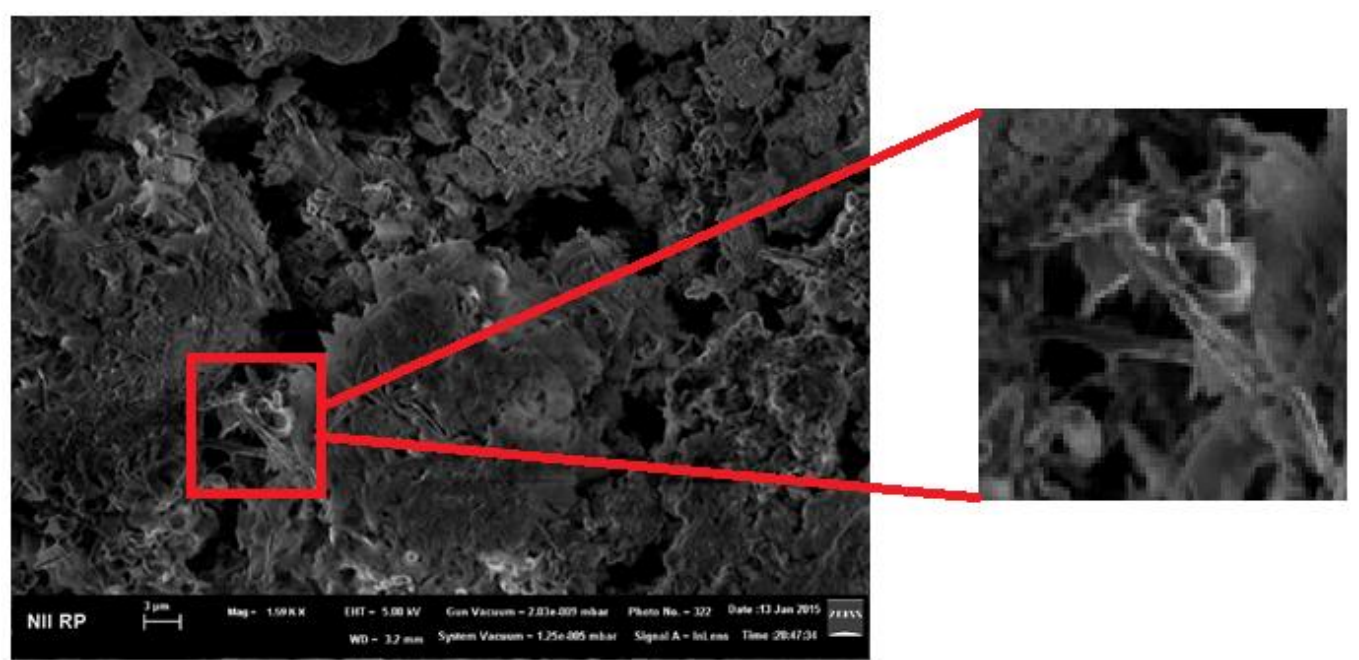

Fig. 4. Surface morphology of $\mathrm{Cu}-\mathrm{Zn}-\mathrm{O}$ nanoparticles.

The study of the influence of the nature of $\mathrm{Me}$ on the formation of phases and surface morphology is shown using the example of $\mathrm{Cu}-$ $\mathrm{Zn}$ (1:1). Interpretation of the XRD results showed the formation of oxides $\mathrm{CuO}$ (PDF 010801916) (monoclinic structure) and $\mathrm{ZnO}$ (PDF 010800075) (hexagonal structure). Calculations using the Scherrer equation showed that copper oxides have a dimension of less than 20 $\mathrm{nm}$, zinc oxides $-12.5 \mathrm{~nm}$. The study of the surface morphology of $\mathrm{Cu}-\mathrm{Zn}-\mathrm{O}$ (Figure 4) showed that there are formations in the form of rods on the surface, which resembles those on the surface of the $\mathrm{Cu}-\mathrm{Co}-\mathrm{O}$ system. However, here they are located chaotically, while in the second case they are as if directed from the center to the surface, i.e. have a direction.
Comparing surface morphology of studied systems it can be assumed that the "hot spots" of the system are copper ions, what contributes to their rapid reduction by polyols, and then around them there is a concentration of other ions and a complex interaction occurs between them.

Catalytic activity of systems in $\mathrm{CO}$ oxidation The catalytic activity of the synthesized $\mathrm{Cu}-\mathrm{Me}$ systems was studied in the oxidation of $\mathrm{CO}$ in the presence of $\mathrm{H}_{2}$ at a volume gas flow rate of $10800 \mathrm{~h}^{-1}$.

As can be seen from Figure 5, the most active were cobalt-copper systems, on which the full conversion of $\mathrm{CO}$ reached at 190$200^{\circ} \mathrm{C}$. The maximum degree of $\mathrm{CO}$ conversion on copper-nickel catalyst was $76 \%$ at $230^{\circ} \mathrm{C}$, the system did not worked stably. 


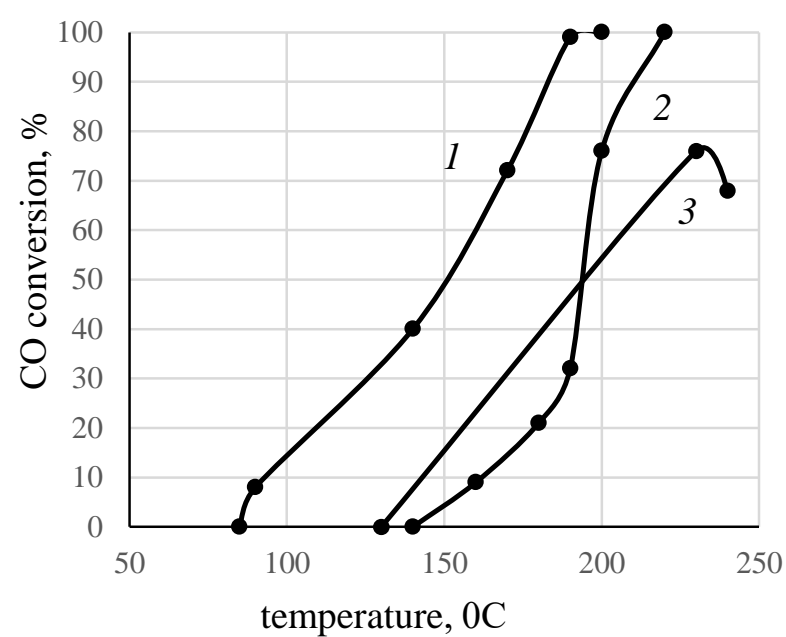

Fig. 5. Temperature dependence of $\mathrm{CO}$ conversion in the presence of $\mathrm{H}_{2}$ on samples: $1-\mathrm{Cu}-\mathrm{Co}-\mathrm{O} ; 2-\mathrm{Cu}-\mathrm{Zn}-\mathrm{O}$; $3-\mathrm{Cu}-\mathrm{Ni}-\mathrm{O}$.

Influence of synergistic effect was studied and shown in Figure 6. As can be seen from the figure, the bimetallic system is more active. Cobalt oxide is more active than copper oxide. Cobalt spinel high activity is possibly explained due to the octahedrally coordinated cation, which exhibits adsorption properties with respect to $\mathrm{CO}$ and helps to reduce the activation barrier of the reaction between adsorbed $\mathrm{CO}$ and oxygen. In addition, it is possible that rapid switching between $\mathrm{Co}^{3+} / \mathrm{Co}^{2}$ ${ }^{+}$ions and a high capacity for oxygen storage contributes to high activity. The high activity of

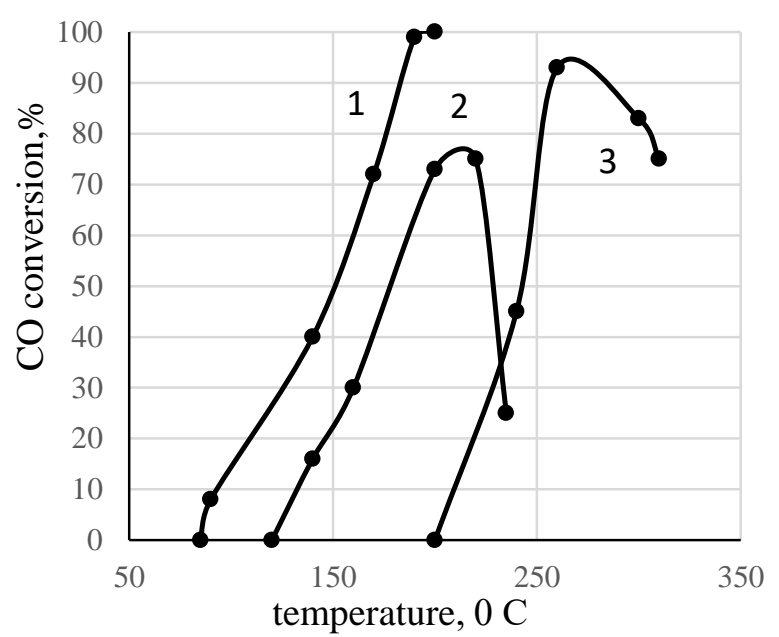

Fig. 6. Temperature dependence of $\mathrm{CO}$ conversion in the presence of $\mathrm{H}_{2}$ on samples: $1-\mathrm{Cu}-\mathrm{Co}-\mathrm{O} ; 2-\mathrm{Cu}-\mathrm{O} ; 3-$ $\mathrm{Cu}-\mathrm{O}$.

the bimetallic system is probably associated with the high oxidizing ability of $\mathrm{Co}^{3+}$ to the states of $\mathrm{Co}^{2+}$, that leads to high oxygen mobility, and the correction of the composition by activation with copper cation is likely to improve the surface's ability to reduce and leads to an improvement in the movement of oxygen from the lattice volume to the surface, that ultimately leads to efficient $\mathrm{CO}$ oxidation.

The influence of $\mathrm{Cu} / \mathrm{Co}$ metal ratio on the aktivity has been studied in the temperature range $70-230^{0} \mathrm{C}$, volumetric velocity $11016 \mathrm{~h}^{-1}$ and is shown in Figure 7.

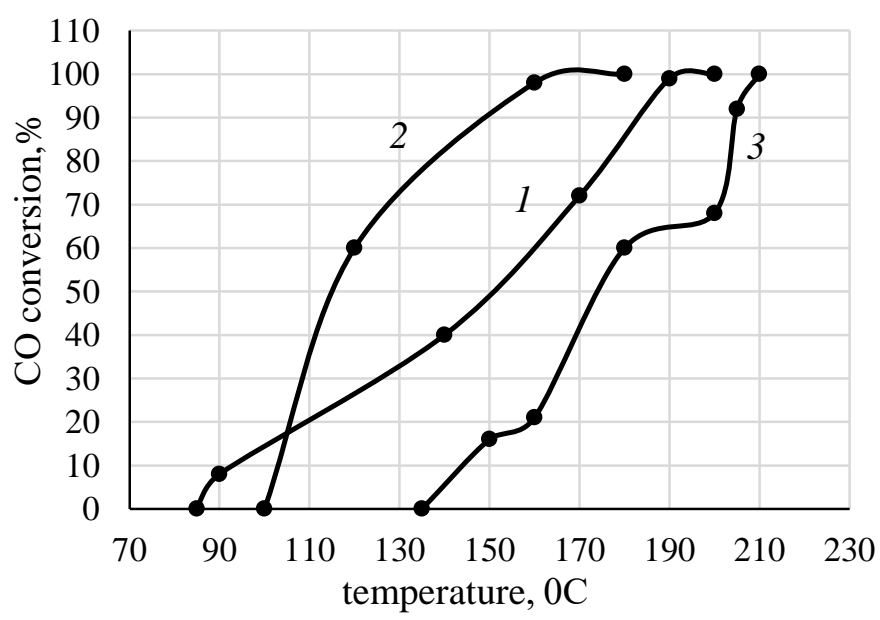

Fig. 7. Temperature dependence of $\mathrm{CO}$ conversion in the presence of $\mathrm{H}_{2}$ on $\mathrm{Cu}-\mathrm{Co}-\mathrm{O}$ samples depending on the ratio $\mathrm{Cu} / \mathrm{Co}: 1-\mathrm{Cu} / \mathrm{Co}=1 ; 2-\mathrm{Cu} / \mathrm{Co}=1 / 2 ; 3-\mathrm{Cu} / \mathrm{Co}=1 / 4$. 
As can be seen from the figure, catalysts have maximum activity in the temperature range $180-220^{\circ} \mathrm{C}$. The catalyst with the $\mathrm{Cu} / \mathrm{Co}=1 / 2$ ratio has the highest activity, which differs from the other smaller size of nanoparticles $(30-35 \mathrm{~nm})$. In addition, the high activity of this sample may also be due to the facets of $\mathrm{Co}_{3} \mathrm{O}_{4}$, as well as the presence of $\mathrm{CoO}$ tetragonal structure, which oxidizes at high temperatures to form a faceted $\mathrm{Co}_{3} \mathrm{O}_{4}$ with a surface enriched with $\mathrm{Co}^{3+}$ [17]. The study of the influence of the $\mathrm{Cu} / \mathrm{Co}$ ratio on the activity has shown that there is a certain limit of copper introduction into cobalt oxide, at which the highest activity is observed among the investigated.

Thus, by hydrothermal reduction of metal salts with subsequent calcination, oxide materials with pronounced nanostructure (12.5 to $140 \mathrm{~nm}$ ) were obtained. $\mathrm{Cu}-\mathrm{Co}-\mathrm{O}$ particles are nanoplates $(30-35 \mathrm{~nm})$ and $\mathrm{Cu}-\mathrm{Zn}-\mathrm{O}(12.5-20$ $\mathrm{nm})$ nanorods. SEM microphotographs have shown that the $\mathrm{Cu}-\mathrm{CoO}$ particles are more structured than the $\mathrm{Cu}-\mathrm{Zn}-\mathrm{O}$ particles. Among the $\mathrm{Cu}-\mathrm{Me}$ oxide systems ( $\mathrm{Me}-\mathrm{Co}, \mathrm{Zn}, \mathrm{Ni}$ ), the $\mathrm{Cu}-\mathrm{Co}-\mathrm{O}$ nanoparticles showed the highest activity, that is probably explained by the redox properties of cobalt oxides and improved oxygen supply from volume to surface due to the modification of cobalt oxides with copper. To be highly active, a catalytic particle must have not only high dispersion, but also a structural organization determined by the morphology and nature of the surface.

This work was carried out with the financial support of SOCAR (Grant No. 07 from 2014-2016 "Synthesis of catalysts for the production and purification of hydrogen for fuel cells").

\section{References}

1. Yaidelin A. Manrique, Carlos V. Miguel, Diogo Mendes, Adelio Mendes. Modeling and Simulation of a Packed-bed Reactor for Carrying out the Water-Gas Shift Reaction. International J. Chemical Reactor Engineering. 2012. V. 10. Issue 1. P. 1542-6580.

2. Laurent Piccolo, Salim Nassreddine, Franck Morfin Surface study of the hydrogen-free or preferential oxidation of CO: Iridium vs. platinum. Catalysis Today. 2012. V. 189. Issue 1. P. 42-48.
3. Zong $\mathrm{Hu}$, Xiaofei Liu, Dongmei Meng, Yun Guo, Yunglong Guo, Guanzhong Lu. Effect of Ceria Crystal Plane on the Physicochemical and Catalytic Properties of $\mathrm{Pd} / \mathrm{Ceria}$ for $\mathrm{CO}$ and Propane Oxidation. ACS Catal. 2016. V. 6. No 4. P. 22652279.

4. Xinli Zhu Min Shen Lance L.Lobban Richard G.Mallinson. Structural effects of $\mathrm{Na}$ promotion for high water gas shift activity on $\mathrm{Pt}-\mathrm{Na} / \mathrm{TiO}_{2}$. J. Catalysis. 2011. V. 278. Issue 1. P. 123-132.

5. Carabineiro S.A.C., Bogdanchikova N., Tavares P.B., Figueiredo J.L. Nanostructured iron oxide catalysts with gold for the oxidation of carbon monoxide. RSC Advances. 2012. V. 2. No 7. P. 2957.

6. Centeno M.Á., Reina T.R., Ivanova S., Laguna Ó.H., Odriozola J.A. $\mathrm{Au} / \mathrm{CeO}_{2}$ Catalysts: Structure and CO Oxidation Activity. Catalysts. 2016. 6. 158. DOI: 10.3390/catal6100158.

7. Amini, E., Rezaei, M. Preparation of mesoporous $\mathrm{Fe}-\mathrm{Cu}$ mixed metal oxide nanopowder as active and stable catalyst for low-temperature $\mathrm{CO}$ oxidation. Chinese Journal of Catalysis. 2015. V. 36. No 10. P. 1711-1718.

8. Jing Wanga, Caiyun Hana Xiaoya Gaoa Jichang Lua Gengpin Wanab. Rapid synthesis of Fe-doped $\mathrm{CuO}-\mathrm{Ce}_{0.8} \mathrm{Zr}_{0.2} \mathrm{O}_{2}$ catalysts for $\mathrm{CO}$ preferential oxidation in $\mathrm{H}_{2}$-rich streams: Effect of iron source and the ratio of $\mathrm{Fe} / \mathrm{Cu}$. J. Power Sources. 2017. V. 343. P. 437-445.

9. Kanaparthi Ramesh, Luwei Chen, Fengxi Chen, Yan Liu, Zhan Wang, Yi-Fan Han. Re-investigating the $\mathrm{CO}$ oxidation mechanism over unsupported $\mathrm{MnO}, \mathrm{Mn}_{2} \mathrm{O}_{3}$ and $\mathrm{MnO}_{2}$ catalysts. Catalysis Today. 2008. V. 131. No 1. P. 477-482.

10. Sajad Mobini, Fereshteh Meshkani, Mehran Rezaei. Synthesis and characterization of nanocrystalline copper-chromium catalyst and its application in the oxidation of carbon monoxide. Process Safety and Environmental Protection. 2017. V. 107. P. 181-189.

11. Ch Anil, Giridhar Madras. Kinetics of CO oxidation over $\mathrm{Cu}$ doped $\mathrm{Mn}_{3} \mathrm{O}_{4}$. J. Molecular Catalysis A: Chemical. 2016. V. 424. P. 106-114.

12. Tabakova T., Avgouropoulos G., Papavasiliou J., Manzi M., Bokuzzi H., Tenchev K., Vinidigni F., Jaoannide T. CO-free hydrogen production over $\mathrm{Au} / \mathrm{CeO}_{2}-\mathrm{Fe}_{2} \mathrm{O}_{3}$ catalysts: Part 1. Impact of the support composition on the performance for the preferential $\mathrm{CO}$ oxidation reaction. Applied. $\mathrm{Ca}-$ talysis B: Environmental. 2011. V. 101. Issues 34. P. 256-265.

13. Mahmood Andache, Ali Nemati Kharat, Mehran Rezaei. Preparation of mesoporous nanocrystalline $\mathrm{CuO}-\mathrm{ZnO}-\mathrm{Al}_{2} \mathrm{O}_{3}$ catalysts for the $\mathrm{H}_{2}$ purification using catalytic preferential oxidation of $\mathrm{CO}(\mathrm{CO}-$ PROX). In. J. Hydrogen Energy. 2019. V. 44. Issue 50. P. 27401-27411. 
14. Dey S., Dhal G.C. Deactivation and regeneration of hopcalite catalyst for carbon monoxide oxidation: a review. Materials today chemistry. 2019. V. 14. 100180.

15. Yafei Guo, Jin Lin, Jian Sun, Jubing Zhang, Changhai Li, Shouxiand Lu. Precursor Effects on Catalytic Behaviors of Copper-Manganese-Cerium Ternary Oxides Pellets for Low-Temperature CO Oxidation. Catalysis Letters. 2019. pp 1-13.
16. Dzhafarova S.T., Medzhidov A.A., Akhmedov M.M., Ialchin B., Fatullaeva P.A., Agaeva S.A., Abbasov M.G. Poluchenie nanorazmernykh poroshkov metodom gidrotermalnogo sovmestnogo razlozheniia nitratov $\mathrm{Cu}, \mathrm{Co}$ i $\mathrm{Al} v$ poliolno srede. Azer. him. zhurn. 2018. № 2. S. 20-26.

17. Kathleen Mingle, Jochen A. Lauterbach, Synthesis-Structure-Activity Relationships in $\mathrm{Co} 3 \mathrm{O} 4$ Catalyzed CO Oxidation / Front. Chem. 25 May 2018 /https://doi.org/10.3389/fchem. 2018. 00185.

\section{NANOÖLÇÜLÜ Cu-Me (Me-Co, Zn, Ni) OKSID SISTEMLəRIN SINTEZI, XÜSUSIYYYЭTLəRİ VӘ CO-nun $\mathrm{H}_{2}$ İŞTIRRAKI İLə OKSIDLOŞMəSI REAKSIYYASINDA AKTIVLIYYi}

\section{S.T.Cəfərova}

Metal duzlarının sonrakı közərdilməsi ilə hidrotermal reduksiya üsulu ilə $\mathrm{Cu}-\mathrm{Me}(\mathrm{Me}-\mathrm{Co}, \mathrm{Zn}, \mathrm{Ni}$ ) tərkibində olan nanooksidlər sintez edilmiş və onların xüsusiyyətlərinin (ölçüsü, morfologiyası, quruluşu) CO-nun $\mathrm{H}_{2}$ iştirakı ilə dərin oksidləşməsi reaksiyasında katalitik aktivliyə təsiri diqqətə alınmışdır. Nanooksidlər RFA və SEM üsulları ilə xarakterizə olunmuşdur. Müəyyən edilmişdir ki, $\mathrm{Cu}-\mathrm{Co}-\mathrm{O}$ hissəcikləri nanolövhələr $(30-35 \mathrm{~nm}), \mathrm{Cu}-\mathrm{Zn}-\mathrm{O}$ hissəciklərisə (12.5-20нм) nanocubuqlar şəklindədilər. SEM üsulu ilə $\mathrm{Cu}-\mathrm{Co}-\mathrm{O}$ hissəciklərinin $\mathrm{Cu}-\mathrm{Zn}-\mathrm{O}$-dan daha yüksək bir quruluş təşkilatını ortaya qoyması müşahidə edilmiş; nanokristalların böyüməsi şəkil miqyasının böyüməsini dəyişdirərək göstərilmiş̧ir. $\mathrm{Cu}-\mathrm{Co}-\mathrm{O}$ sisteminin qeyd olunan və müvafiq fərdi oksidlər arasında ən yüksək aktivliyə malik olması müəyyən edilmişdir. Metalların nisbətinin $(\mathrm{Cu} / \mathrm{Co})$ nanohissəciklərin dispersiyasına və morfologiyasına və onların aktivliklərinə təsiri tədqiq edilmişdir. Aktivliyin qeyri-additiv artması kobalt oksidlərin oksidləşmə-reduksiya xüsusiyyətləri və misin onun elektron vəziyyətinə verdiyi töhfə ilə izah olunmuşdur. Tərkibinin dəyişməsi və həmçinin yüksək dispersiya (30-35nm) CO-nun oksidləşmə başlanğıcının $\left(\mathrm{T}_{50 \%}\right)$ temperaturunu $115^{\circ} \mathrm{C}$-dən aşağı salmağa imkan verir.

Açar sözlor: nanooksidlar, nanolövhalər, nanoçubuklar, modifikasiya, morfologiya, quruluş, CO oksidlaşma, elektron mikroskopiya.

\section{СИНТЕЗ, ХАРАКТЕРИСТИКА И АКТИВНОСТЬ НАНОРАЗМЕРНЫХ $\mathrm{Cu}-\mathrm{Me}(\mathrm{Me}-\mathrm{Co}, \mathrm{Zn}, \mathrm{Ni})$ ОКИСНЫХ СИСТЕМ В ОКИСЛЕНИИ СО В ПРИСУТСТВИИ Н}

\section{С.Т.Джафарова}

Методом гидротермального восстановления солей металлов с последующим прокаливанием синтезированы нанооксиды состава $\mathrm{Cu}-\mathrm{Me}(\mathrm{Me}-\mathrm{Co}, \mathrm{Zn}, \mathrm{Ni})$ и рассмотрено влияние их свойств (размер, морфология, структура) на каталитическую активность в реакции глубокого окисления $\mathrm{CO}$ в присутствии $\mathrm{H}_{2}$. Нанооксиды охарактеризованы методами РФА и СЭМ. Выявлено, что частицы $\mathrm{Cu}-\mathrm{Co}-\mathrm{O}$ представляют собой нанопластины (30-35нм), а $\mathrm{Cu}-\mathrm{Zn}-\mathrm{O}(12.5-20 \mathrm{Hм})$ наностержни. Методом СЭМ обнаружена более высокая структурная организация частиц $\mathrm{Cu}-\mathrm{Co}-\mathrm{O}$, чем $\mathrm{Cu}-\mathrm{Zn}-\mathrm{O}$; в варьировании увеличении масштабной сетке изображений показан рост нанокристаллов. Установлена наибольшая активность системы $\mathrm{Cu}-\mathrm{Co}-\mathrm{O}$ среди упомянутых и соответствующих индивидуальных оксидов. Изучено влияние соотношения металлов $(\mathrm{Cu} / \mathrm{Co})$ на дисперсность и морфологию наночастиц и их активность. Неаддитивное повышение активности объяснено окислительновосстановительными свойствами оксидов кобальта и вкладом меди в его электронное состояние. Варьирование состава, а также высокая дисперсность (30-35нм) дает возможность снизить температуру начала окисления $\left(\mathrm{T}_{50 \%}\right) \mathrm{CO}$ до менее $115^{\circ} \mathrm{C}$.

Ключевые слова: нанооксиды, нанопластины, наностержни, модифииирование, морфология, структура, окисление СО, электронная микроскопия. 